\title{
Russia’s Asymmetric Wars in Chechnya since 1994
}

\section{Martin Malek ${ }^{*}$}

\section{Concepts of Asymmetrical Warfare}

Some military theorists define military symmetry not in terms of quantitative parity but in terms of qualitative similarity. According to Herfried Münkler from the Berlin-based Humboldt University, forces are symmetric when they recruit, arm, and train their combatants in a similar way. ${ }^{1}$ In the days of Carl von Clausewitz (1780-1831), wars were seen from an essentially state-centric perspective: In the pursuit of their national interests, states fought other states. European armed forces began to transform into symmetrical state armies in the sixteenth and seventeenth centuries, and symmetrical warfare continued to characterize European wars until the twentieth century. Historically, symmetrical warfare was not the norm, but rather a European anomaly. Münkler states that Europe's exceptionalism in this respect might be coming to an end. ${ }^{2}$ Today's protracted low-intensity wars seem to point back towards the era of asymmetrical warfare. This development is obviously closely linked to the phenomenon of state failure in Third World countries, in southern regions of the former USSR, and in the Western Balkans.

Features of "New Wars" and the Chechen War

The conflict in the tiny North Caucasian republic of Chechnya that has raged on and off since the fall of 1994, is quite characteristic of today's endemic wars, which have often been distinguished from previous symmetric wars by the addition of such modifiers as "new," "small," "post-national," etc. Academics have highlighted following features of these "new" wars: ${ }^{3}$

Martin Malek is a Senior Research Fellow at the Austrian National Defense Academy in Vienna and Austrian representative in the PfP's Regional Stability in the Greater Black Sea Area Working Group.

1 Herfried Münkler, Der Wandel des Krieges: Von der Symmetrie zur Asymmetrie (Weilerswist: Velbrück, 2006), 60.

2 Herfried Münkler, "Wandel der Weltordnung durch asymmetrische Kriege," in Asymmetrische Kriegsführung - ein neues Phänomen der Internationalen Politik?, eds. Josef Schröfl and Thomas Pankratz (Baden-Baden: Nomos, 2004), 91.

3 Ulrich Beck, Der kosmopolitische Blick, oder Krieg ist Frieden (Frankfurt am Main: Suhrkamp, 2004); Michael Brzoska, “New Wars' Discourse in Germany," Journal of Peace Research 41:1 (2004): 275-82; Christopher Daase, Kleine Kriege - große Wirkung: Wie unkonventionelle Kriegsführung die internationale Politik verändert (Baden-Baden: Nomos, 1999); Mary Kaldor, New and Old Wars: Organized Violence in a Global Era (Stanford, CA: Stanford University Press, 1999); Herfried Münkler, "Die privatisierten Kriege des 21. Jahrhunderts," Merkur 55:623 (March 2001): 222-34; Herfried Münkler, Die neuen Kriege (Reinbek bei Hamburg: Rowohlt, 2002). 
- The "new asymmetry" is related to state failure. When a state fails, a struggle occurs between state power and non-state actors (who might be attempting to assert their own statehood). However, it is often unclear whether the conflicts in the regions mentioned above are the cause or the result of state failure. Therefore, in the majority of the cases the interdependency between the rise of violent non-state actors and the decay of state power is evident.

- The "new wars" are connected with failing state power in the affected regions. Thus, the state's monopoly on the legitimate use of force (a concept developed by Max Weber) has been compromised or even suspended.

- The traditional "division of labor" between the government, the fighting (and dying) soldiers of the military, and the civilian population has changed. In the "new wars," political leadership, military leadership, and actual fighting overlap.

- Non-state actors usually lack regularly mustered and bureaucratically administrated armed forces. Such actors have no access to high-tech weapons, and therefore rely primarily on light arms. This makes it difficult for traditional state-run armies to identify and engage such forces. Martin van Creveld contended that all armies that fought low-intensity wars systematically tortured and terrorized their opponents (killing civilians, etc.). ${ }^{4}$ The Russian troops in Chechnya acted likewise. Referring to this conflict, Creveld equated asymmetric warfare with counter-insurgency operations. ${ }^{5}$

- The increasing privatization of wars has reversed the evolution of statecontrolled armies, and thus blurred the distinction between regular soldiers and bandits. In the "new wars," soldiers are no longer necessarily agents of legitimate state power, but rather increasingly are free agents pursuing their own economic interests.

- "New wars" lack clear-cut front lines (a term associated with the modern nation-state), and therefore the civilian population is affected more directly by military action.

- The "new wars" are fought in the middle of the civilian population, and consequently often result in significant collateral damage. In addition, in many conflict zones the civilians face repression, and are often targeted deliberately. Hence small arms can take a heavy toll of civilian lives. Similar to

4 Martin van Creveld, Die Zukunft des Krieges (München: Gerling Akademie Verlag, 1998), 58.

5 Martin van Creveld, "Grausamkeit oder Zurückhaltung. Wie reguläre Armeen asymmetrische Kriege gewinnen können,” Internationale Politik 61:4 (2006): 87. 
other wars in the late twentieth century, civilian casualties in the two Chechen wars by far outnumbered the military losses. Due to the extremely high civilian death toll (some estimate up to 200,000 killed), the Russian troops can hardly be viewed as protective forces, but rather as the primary security threat to most of the inhabitants of Chechnya, regardless of their nationality.

- Whereas classical state-centered wars started with a declaration of war and ended with the conclusion of a peace treaty, the "new wars" seldom have clear starting and ending points.

- Weapons technology has improved significantly, resulting in increased firepower, reduced weight, and less complex logistics, enabling smaller forces to inflict more damage.

- Since the 1970s, a phenomenon called "civil war economics" has gained in prominence. Wars metamorphosed from political instruments into vehicles of private profit maximization for government officials, military leaders, warlords, etc. Regarding Chechnya, it has been reported that Russian generals and pro-Russian Chechen officials have been ransacking the Chechen Republic. Oil has been exported illegally, and funds (allegedly) earmarked for the reconstruction of Chechnya have been misappropriated.

\section{Failed State-Building in Chechnya}

Undoubtedly, post-Soviet Chechen separatism was a major, albeit regionally limited, challenge to Russia's monopoly on state power. ${ }^{6}$ During the breakaway republic's short spells of de facto independence from 1991-94 (under President Dzhokhar Dudayev) and 1996-99 (under President Aslan Maskhadov), the Chechens were unable to build a viable state with a monopoly on the legitimate use of physical force and institutions capable of providing services to its citizens. Chechnya was termed a "failed proto-state." In 1992 and 1993, Chechnya passed through serious internal conflicts and clashes: an attempted coup d'état against Dudayev failed, and in June 1993 he dissolved the parliament to avoid a referendum on a vote of no confidence. However, he was caught in a protracted power struggle with warlords such as Beslan Gantamirov, Umar Avturkhanov, and

6 This cannot be said about the formation of paramilitary groups in North Ossetia in 1991-92, which was tolerated (or even promoted) by Moscow. With the support of North Ossetian security forces and the Russian military, these paramilitaries managed to drive about 65,000 Ingush out of the Prigorodny district within a few days at the beginning of November 1992. The North Ossetian paramilitaries still exist. However, to this day the Kremlin has never labeled them "bandits" or "terrorists" or called for their "eradication" (as it routinely does with the Chechen rebels). From the Russian perspective, the problem apparently is not the existence of non-governmental forces, but their political orientation.

7 Das Parlament (10 October 2005), 15. 
Ruslan Labazanov, who controlled Chechnya's Urus-Martan and Nadterechny districts. ${ }^{8}$

In December 1994, Russian President Boris Yeltsin ordered troops into Chechnya. By early 1995, they had almost succeeded in dismantling the Chechen "proto-state" by force. However, neither this nor Dudayev's assassination in April 1996 broke the resistance of the Chechen guerilla fighters. In August 1996, they recaptured the capital city, Grozny. Following the armistice later in August, Maskhadov began (with limited success) to rebuild Chechen institutions. In autumn 1998, the American Caucasus specialist Charles Fairbanks identified nineteen different armed groups and institutions in Chechnya, some of which were sworn enemies. ${ }^{9}$ In 1999, the Center for Civil-Military Relations and Security Studies in Tbilisi (Georgia) estimated the number of Chechen troops (official, semi-official, and unofficial troops) at 14,200, a total that did not include some small paramilitary groups. According to the Georgian Center, the Chechen National Guard was estimated at 2500, with Maskhadov's Presidential Guard amounting to another 300 men. The Ministry of the Interior deployed 5,000 men, the "Sharia Ministry for National Security" 900, the "Sharia Guards" 500, and the authorities for tax, customs, and border protection another 500 men altogether. Additional troops were under the command of Salman Raduev (1,000 troops in the "General Dudayev Army"), Shamil Basayev (approximately 1,000 troops and a few tanks and armored vehicles), Anri Baraev (1,000 troops), and the Arab Khattab (three training camps with 1,000 troops, 300 troops with tanks and armored vehicles). Other unofficial groups counted between 50 and 150 armed troops each. ${ }^{10}$ Therefore, in September 1999, when Russia launched its second campaign, there was no Chechen army under a unified command, but instead a large number of scattered units.

\section{The Relative Strengths of Combatants}

According to the Swiss military strategist Albert A. Stahel, in asymmetrical warfare the weaker side will avoid engaging the stronger side head-on; it will instead seek to strike unexpectedly at the opponents Achilles' heel. The superior force, on the other hand, typically faces a dilemma: it can either carpet-bomb the opponent,

8 The former Speaker of the Supreme Soviet of Russia, the ethnic Chechen Ruslan Khasbulatov, was also occasionally involved.

9 Charles H. Fairbanks, "Weak States and Private Armies," in Beyond State Crisis? Postcolonial Africa and Post-Soviet Eurasia in Comparative Perspective, eds. Mark R. Beissinger and Crawford Young (Washington, D.C.: Woodrow Wilson Center Press, 2002), 132.

10 Vakhtang Maisaia, "The Chechen Armed Forces: Contemporary Case," The Army and Society in Georgia (July 1999): 1-4. 
or accept casualties and pursue a more differentiated strategy. ${ }^{11}$ Moscow tried the first approach without, however, managing to avoid the losses that typically accompany the second approach. Stahel states that in asymmetrical warfare, collateral damages are negatively correlated to the casualties of the superior side. ${ }^{12}$ Collateral damage in Chechnya was of little interest to the Russian public and to international audiences (aside from human rights organizations, which had little influence in Russia), and consequently Moscow did not take them into account. Guerilla tactics are more promising in populous regions, since such locales give insurgents the ability to blend into the civilian population. ${ }^{13}$ In the 1980 s, there were about one million inhabitants in all of Chechnya, and during the wars the population was much smaller. ${ }^{14}$

In his theory on asymmetrical warfare, Stahel developed a cost-benefit analysis. ${ }^{15}$ However, the second Chechen war reveals the limitations of such an approach. Moscow seemed prepared to take disproportionate measures in order to bring Chechnya back into the fold. The Kremlin was sacrificing thousands of its soldiers (not even considering the civilian casualties in Chechnya) for a republic that accounts for about 0.1 percent of Russian territory (Chechnya is slightly larger than the State of Connecticut in the northeastern U.S.). The fighting essentially took place in an area of about sixty by thirty kilometers located between the Terek River and the mountainous southern region of Chechnya. ${ }^{16}$ If the Kremlin was a rational decision maker and guided by precise cost-benefit assessments, it would surely have ended its campaign in Chechnya instead of trying to win the war "at any cost." However, especially during the second war, there was little internal or external pressure forcing Moscow to negotiate.

There are several theories available to try to explain the victory of militarily inferior sides in asymmetrical wars. Andrew Mack argues that the militarily superior side may lack resolve because its survival is not at stake. For the weaker side,

11 Albert A. Stahel, "Dissymmetrischer Krieg versus asymmetrischer Krieg," Allgemeine Schweizerische Militärzeitschrift 168:12 (2002): 3.

12 Ibid., 5.

13 Albert A. Stahel, "Simulationen asymmetrischer Kriege," Allgemeine Schweizerische Militärzeitschrift 167:11 (2001): 22.

14 The results of the Russian census for Chechnya in 2002 are not plausible. See Martin Malek, "Russlands Kriege in Tschetschenien: 'Wiederherstellung der verfassungsmäßigen Ordnung,' 'Antiterror-Operationen' oder Völkermord?" Zeitschrift für Genozidforschung 5:1 (2004): 102-29, particularly 119; Paul Goble, "2002 Russian Census Results for Chechnya 'Contradicts Common Sense,"” RFE/RL Caucasus Report 8:32 (15 September 2002); Sergej Maksudov, "Naselenie Chechni: prava li perepis?", available at www.kavkaz-forum.ru/dossier/ 12963.html?print=on; Novye Izvestia (24 October 2002), 1, 5.

15 Stahel, "Dissymmetrischer Krieg versus asymmetrischer Krieg," 5.

16 Uwe Halbach, "Krieg am Rande Europas. Der Tschetschenienkonflikt in neuem Licht?" SWP-Aktuell 45 (November 2002): 4. 
there is often no survival without victory, and hence it compensates for its inferior military might with steadfast determination. ${ }^{17}$ In Chechnya, such determination at times undoubtedly played an important role. In the nineteenth century, the Chechens persistently resisted the Tsarist expansion into the North Caucasus (the Caucasian War of 1817-64). Later, in 1944, the Chechens were collectively deported to Central Asia. In Russia, on the other hand, there is a broad consensus (meaning not only among the Communists, nationalists, and the military) that the future of the entire state hinges upon asserting Russian sovereignty in Chechnya: Russians feared that Chechen separatism might have a "domino effect," and could ultimately lead to the disintegration of the Russian state (like the Russian Empire at the end of World War I and the USSR in 1991). This fear still exists, although the periods of de facto independence of Chechnya in 1991-94 and 1997-99 did not encourage other regions to seek independence. When examining the course of the two wars since 1994, there was little doubt about Russia's resolve to annihilate the Chechen "bandits and terrorists."

If Mack's hypothesis holds, victory in asymmetric wars should be distributed relatively equally between strong and weak combatants. Ivan Arreguin-Toft, however, concluded that between 1800 and 1998 the "weak actor" prevailed more often than not (in 55 percent of the conflicts in the period from 1950 to 1998). ${ }^{18} \mathrm{Ar}-$ reguin-Toft defined asymmetry as a condition in which the relative strength of the combatants is at least 5:1. Furthermore, he identified two fundamental strategies for both the stronger and the weaker sides. The stronger side can either focus on destroying the military capabilities of the opponent ("direct attack") or try to demoralize the opponent by systematically violating the laws of war and ruthlessly targeting the civilian population ("barbarism"). The weaker side, on the other hand, can adopt a conventional defense strategy ("direct defense," relying on its armed forces to protect its territory, population and strategic resources) or opt for guerilla tactics.

Arreguin-Toft distinguishes between "direct" and "indirect" strategies. While direct strategies target the military forces of the opponent in order to destroy his capabilities to continue the fight, indirect strategies aim at demoralizing the opponent. Guerilla fighters attack the soldiers of a superior adversary, and the civilian population suffers from barbarism inflicted by the stronger force. Arreguin-Toft argues that the weaker side prevails when the two opponents adopt different approaches ("direct vs. indirect" or "indirect vs. direct"). It is difficult to classify the Chechen war into these categories, since the Russian forces adopted both direct

17 Andrew Mack, "Why Big Nations Lose Small Wars: The Politics of Asymmetric Conflict," World Politics 27:2 (1975): 181.

18 Ivan Arreguin-Toft, "How the Weak Win Wars: A Theory of Asymmetric Conflict," International Security 26:1 (2001): 97-99. 
and indirect strategies, attacking the Chechen military forces while terrorizing the Chechen populace. According to Arreguin-Toft's theory, in the case of a combination of "barbarism" and "guerilla warfare," the stronger combatant - the Russian Army-would win. ${ }^{19}$ While this was not the case in the first Chechen war, the Russians won the second war.

\section{The Russian-Chechen Military Balance}

\section{The Chechen Forces before the First War}

After the failed coup in Moscow in August 1991, Dudayev, a Major General of the Soviet Air Force, seized power in Chechnya. Subsequently vast numbers of weapons "disappeared" from Soviet arms caches in the republic. The Russian troops withdrew from Chechnya in 1992. On 28 May 1992, the Russian Minister of Defense General Pavel Grachev instructed the commander of the North Caucasian Military District to hand over 50 percent of the weapons of the $173^{\text {rd }}$ Soviet "detached training center" to the Chechens. According to a later investigation of the General Staff of the Russian Armed Forces, Dudayev received far more weapons, in particular two rocket artillery systems, 42 tanks, 48 armored vehicles, 139 artillery systems, 89 antitank guided weapons, 118 surface-to-air missiles, 37,795 small arms, 27 wagons of ammunition, 44 lightly armored transport vehicles, 942 automobiles, 1620 tons of fuel, and 260 training aircraft (L-29 and L-39). ${ }^{20}$ However, it is questionable how many of these weapons were in working order. The Russian Air Force destroyed most of the Chechen aircraft in late November/early December 1994, and by all accounts there have been no significant deployments of Chechen tanks during the war.

\section{The Russian Intervention Force in the First War}

On 11 December 1994 the Russians invaded Chechnya with 23,700 troops (19,000 from the Ministry of Defense and 4,700 from the Ministry of the Interior, or MVD), 80 tanks, 208 armored vehicles, and 182 short-range artillery systems/ mortars. Expecting a swift victory, the Russian force had been hastily assembled from different units. ${ }^{21}$

According to most sources, the level of Russian forces in Chechnya never exceeded 45,000 troops during the first war (which was over by 1996). But in a publication edited by a professor of the Russian Academy of Military Sciences, the Russian intervention force in Chechnya was estimated at 70,509 troops (including

19 Ibid., pp. 100-109.

20 Tatyana I. Kasatkina, ed., Rossiya - Chechnya: Tsep oshibok i prestuplenii (Moscow: Zvenya, 1998), 105.

21 Pavel Felgenhauer, "Russian Strategy in the Chechnya Wars," Parameter bewaffneter Konflikte. Studien und Berichte zur Sicherheitspolitik 4, Schriftenreihe der Landesverteidigungsakademie (Vienna, September 2000): 89. 
58,739 combat troops) as of 1 February 1995, along with 322 tanks, 2100 armored vehicles, and 627 short-range artillery systems/mortars. ${ }^{22}$ The huge differences in the estimates might be explained by the inclusion of the Russian Militia (Police) and personnel from the OMON (riot police), the FSK/FSB (counter-intelligence service), and the GRU (military intelligence) in the latter estimates. Nevertheless, the overall military strength of the Russian forces deployed during the first war remains unclear.

\section{The Chechen Forces in the Second War}

According to a Russian newspaper, the Chechen forces available at the outset of the second war in Chechnya consisted of 40,000 troops, 15 tanks, 3 self-propelled artillery systems, 5 "Grad" multiple rocket launchers, approximately 20 field guns, 16 air defense systems, up to 40 surface-to-air missiles, and about 500 different anti-tank weapons. ${ }^{23}$ According to the official Russian military newspaper Red Star, Chechen forces were composed of 2,000 presidential guards, 1,500 "army" troops ready for action, and another 15,000 in the process of mobilization. In addition, there were various other armed formations (such as the troops under the command of the infamous Shamil Basayev ${ }^{24}$ ), troops of the "Sharia Ministry for State Security," and units of the Chechen Ministry of the Interior. ${ }^{25}$

22 Grigoriy F. Krivosheyev, ed., Rossiya i SSSR v voynakh XX veka. Poteri vooruzhennykh sil. Statisticheskoe issledovanie (Moscow: OLMA-Press, 2001), 582. Some Russian sources estimated the number Russian troops at 80,000 during the first Chechen war; see Aleksei Malashenko and Dmitri Trenin, Vremya yuga. Rossiya v Chechne - Chechnya v Rossii (Moscow: Gendalf, 2002), 143.

Nezavisimoe voennoe obozrenie 42 (1999): 2.

24 Moscow justified the two Chechen campaigns by claiming that it was defending the (allegedly) challenged territorial integrity of Russia. At the same time, Moscow had been supporting armed separatists in the Dnestr region (Moldova), Abkhazia, South Ossetia (Georgia), and Nagorno Karabakh (Azerbaijan) - regions that had managed to secede by force from their central governments in the early 1990s. Basayev's “career" illustrates particularly well the Russia double standards with regard to separatism and irredentism in the CIS. In 1992, he fought on the side of the pro-Russian Abkhaz separatists against the weaker Georgian forces. The Georgians were defeated and driven out of Abkhazia in 1993. In the eyes of Moscow, Basayev mutated into a "bandit" and "terrorist" only after he began to support the Chechen separatists in the first Chechen war. There is little doubt that Basayev worked together well with Russian secret services in Abkhazia (where Basayev's men are said to have played soccer with the heads of killed Georgians). Statements by the former head of the FSK, Sergei Stepashin, and the former President of Ingushetia, General Ruslan Aushev, support this view. See Leonid Mlechin, Kreml. Prezidenty Rossii. Strategiya vlasti ot B.N. Yeltsina do V.V. Putina (Moscow: Tsentrpoligraf, 2002), 436; Vladimir A. Zolotarev, ed., Rossiya (SSSR) v lokalnykh voynakh $i$ voennych konfliktakh vtoroy poloviny XX veka (Moscow: Kuchkovo Pole, 2000), 48 (this is a publication of the Institute for Military History under the Russian Ministry of Defense). 
The statements of the Russian forces and their Chechen accomplices regarding the military strength of the rebels and the rebel casualties are usually contradictory, and often implausible. For example, in August 2006, Ramzan Kadyrov, the Russian-backed Chechen Prime Minister, claimed that there were only ninety rebels left (including thirty Arab mercenaries). On 1 December 2006 the Commander of the Troops of the MVD, Colonel General Nikolai Rogozhkin, put the number of the remaining Chechen fighters at 800 to 1,000 . But in any case it was unclear from a military point of view why Moscow needed tens of thousands of soldiers and paramilitary troops in order to get these few rebels under control.

\section{The Russian Intervention Force in the Second War}

In late September 1999, Russia mounted a weeks-long air campaign over Chechnya, followed by a ground invasion at the beginning of October 1999. On 1 December 1999 there were some 100,000 Russian soldiers deployed in Chechnya (not including MVD Troops, police forces, and the OMON). They were equipped with 1650 tanks/armored vehicles and 480 rocket artillery systems. ${ }^{26}$ This military build-up violated the restrictions of the Treaty on Conventional Armed Forces in Europe for the Southern flank (as had been the case during the first war). Moscow did not deny this fact, but justified the action by claiming that its "national security" was at stake. The Kremlin announced that it would keep to the agreement only after the campaign in Chechnya had been brought to an end.

In autumn 2002, the Russian forces in Chechnya were composed of: the $42^{\text {nd }}$ Motorized Army Division (15,000 troops); battalions from various military precincts $(22,000)$; paratroopers $(3,000)$; the $46^{\text {th }}$ MVD Brigade $(10,000)$; OMON units from all over Russia, as well as the SOBR rapid reaction force (together $4,000)$; border troops $(6,000)$; and the FSB. In addition, there were special forces units from the FSB, GRU, and MVD ("Alfa," "Vympel," "Vitjas," "Skif," "Fakel," etc.), as well as railroad troops, units of the Ministry for Emergency Situations and Civil Defense, construction troops, and so on. ${ }^{27}$ In sum, the Russian troops in Chechnya amounted to approximately 100,000 men. The Russian $4^{\text {th }}$ Air Force Division, headquartered in Rostov-on-Don, flew sorties over Chechnya, but also bombarded areas in northern Georgia (particularly in the area of the Pankisi Gorge) where Moscow suspected that there were rebel bases. Meanwhile, the $58^{\text {th }}$ Army was firing Luna-9M and Tochka- $U$ missiles at both civilian and military targets in Chechnya from encampments in the North Ossetian capital of Vladikavaz.

Chechnya and its neighbor Ingushetia undoubtedly belong to the most highly militarized regions in Russia. ${ }^{28}$ On 2 March 2005, the Russian Minister of Defense Sergei Ivanov said that, including troops from all the Russian security-related state

\footnotetext{
26 Nezavisimoe voennoe obozrenie 50 (1999): 2.

27 Novaya gazeta (18 November 2002), 2.

28 Nezavisimaya gazeta (17 May 2005), 2.
} 
bodies, there were altogether 80,000 personnel stationed in Chechnya (including 30,000 from his ministry). ${ }^{29}$ In July 2006 , Ivanov claimed that there were 23,000 troops from his ministry in Chechnya. ${ }^{30} \mathrm{~A}$ month later, Ivanov said that there were less than 20,000 Defense Ministry troops (mainly the $42^{\text {nd }}$ Division and Special Forces) still deployed in Chechnya. This would mean that between March 2005 and August 2006 more than 10,000 MoD troops had been withdrawn. Even the Moscow-based daily Nezavisimaya gazeta, generally a staunch supporter of the Kremlin, noted that this would have constituted a major troop movement-one which, surprisingly, nobody in Russia noticed. ${ }^{31}$ In early 2006, the same newspaper reported that the number of MVD troops in and around Chechnya had increased in $2005 .^{32}$ In late 2006, Rogozhkin disclosed that the personnel of the $46^{\text {th }}$ MVD Brigade had been increased by 5,000 servicemen, bringing it to a total of 15,000 troops. $^{33}$ This did not fit the positive picture the Kremlin preferred to paint about its "successful campaign" against the Chechen rebels that was (allegedly) coming to an end. ${ }^{34}$

In addition to the Russian federal troops, there were also troops present that were financed and maintained by the pro-Russian administration in Chechnya. Their primary purpose was to "Chechenize" the conflict and to let pro-Russian Chechens fight the rebels. However, it has been mockingly said that this has not led to a "Chechenization" but to a "Kadyrovization" of the conflict (referring to the limited support enjoyed by the Russian-backed Chechen puppet leader Kadyrov).

\section{Methods and Character of the War}

\section{A Russian "Anti-Terror Operation”?}

Russian officials and the (directly or indirectly) Kremlin-controlled media seldom use the word war when referring to Chechnya, but instead invoke the terms anti-

29 Nezavisimoe voennoe obozrenie (1 September 2006); available at http://nvo.ng.ru/wars/2006 -09-01/2_troops.html..

30 According to the Nezavizimaya gazeta, there were an additional 24,000 troops of the Russian MVD present in Chechnya (12 July 2006), 5.

31 Ibid.

32 Nezavisimaya gazeta (13 January 2006), 4.

33 Nezavizimaya gazeta (11 November 2006), 8.

34 Russian statements regarding their own casualties are also implausible. In 2005, the Ministry of Defense claimed that, on a monthly average, it lost fourteen or fifteen soldiers, and that only a third of these were killed in action; see Nezavisimaya gazeta (21 March 2006), 4. According to estimates of the "Committees of Soldiers' Mothers of Russia," approximately 25,000 Russian soldiers and officers were killed in both Chechen wars-far more than the official numbers would indicate ("Soldatskie materi soobshchayut, chto v Chechne pogibli bolee 25 tysyach rossiiskikh voennykh," available at www.kavkaz.memo.ru/newstext/news/ id/815160.html. 
terror operation or campaign against bandits. Unlike in the first war, when the Kremlin talked about "reinstating constitutional order" in Chechnya, the second campaign was officially referred to as a "struggle against terrorism." The Kremlin ignored the regional, ethnic, and political roots of the war, and labeled any resistance against its subjugation strategy as "terrorism." By calling the rebels "bandits" and "criminals," the Kremlin endeavored to discredit them domestically and internationally.

Since the terror attacks in the U.S. on 11 September 2001, the Kremlin has stressed that the Chechen war is a part of the "war against international terrorism." At the same time, Moscow objected to any international "interference in its domestic affairs" in Chechnya (including international mediation). Moscow attempted to solve this contradiction by establishing an "international commitment to fight terrorism in Chechnya." 35 The Kremlin occasionally propagated the notion that Chechen resistance was not autochthonous, but rather was controlled externally, presumably by an Islamist movement on the order of Al Qaeda. Moreover, the Kremlin tried to give the impression that the Russian forces were fighting an Islamist "terror army" composed of large numbers of foreign mercenaries. In reality, there were most likely never more than between 200 and 300 foreign combatants involved in the conflict on the Chechen side. ${ }^{36}$ Moscow tried to equate its campaign in Chechnya with the war the U.S. is fighting against the Taliban and Al Qaeda in Afghanistan.

\section{"Barbarian Acts" - Who Is the Real Terrorist?}

According to the Russian military sociologist Major-General Vladimir Serebryannikov, between 80 and 90 percent of the Chechen population (regardless of their ethnicity) resisted the Russian occupation forces (who believed that they would be welcomed as "liberators") during the first Chechen war. ${ }^{37}$ In early 1996, the Russian Deputy Defense Minister General Georgi Kondratyev avowed that "it is the entire Chechen population fighting here, not armed bandits." $" 38$ But this kind of acknowledgement is exceptional. Internally, the Russian occupation forces apparently concluded that the campaign had to be expanded to cover the entire Chechen population. The German OSCE observer Jürgen Heiducoff, who experienced the conflict first-hand, reported in 1995 that "thousands of civilians are exterminated in order to kill ten or perhaps fifteen rebels." Heiducoff claimed that what was

35 "Zayavlenie Pravitelstva Rossiyskoy Federatsii o situatsii v Chechenskoy Respublike i merakh po ee uregulirovaniyu" ("Declaration of the Government of the Russian Federation pertaining to the situation in the Chechen Republic and to regulative measures"), 25 October 1999; available at http://npa-gov.garweb.ru:8080/public/default.asp?no=1481508.

36 Malashenko and Trenin, Vremya yuga, 103.

37 Vladimir Serebryannikov, Sotsiologiya voyny (Moscow: Nauchny mir, 1997), 159.

38 "Itogi," NTV television network (22 January 1995). 
taking place was the annihilation of the Chechen people, and that the Russian forces deliberately caused carnage by firing their heavy weapons at defenseless civilians. ${ }^{39}$ Besides, the policy of aerial carpet bombings makes it impossible to discriminate between rebels and the civilian population. But the Russian forces largely regarded this distinction as superfluous. In the eyes of many Russian officers and soldiers, there was only one way to win the war: "By killing all Chechens, civilians or not." 40 General Sergei Stepashin, who was head of the FSK at the beginning of the first Chechen war, was quoted saying, "to win this war the whole male Chechen population would have to be eradicated." $" 41$

The general state of lawlessness in Chechnya was one reason for Moscow to embark on its campaigns in 1994 and 1999. Vladimir Putin, who at the time of the 1999 offensive had recently assumed the Russian presidency, promised "that we will not use any force against the Chechen people." 42 However, numerous reports by Russian human rights groups and activists, Russian and international media coverage, frank statements of Russian military leaders and, above all, the actions of the Russian Armed Forces on the battlefield confirmed that many soldiers did not regard their Chechen adversaries as humans, but rather as "animals." Respect for Russian and international human rights regulations (such as the Geneva Conventions) was therefore viewed as dispensable. Russian disregard for human rights continued to rally the Chechens, and fueled the recruitment of new rebels (in spite of high casualties). From the Russian perspective, the continuous flow of new rebel recruits justified increasingly radical measures, even against the civilian population. General Gennadi Troshev, commander of the Russian troop formation "East" in the Northern Caucasus in late 1999, outlined his tactics with the following words: "If we are fired at from a house, then we destroy the house. If we are fired at from a village, then we destroy the village."43

So-called filtration camps (first set up in late 1994) served as an instrument to single out Chechens who allegedly had been in contact with the rebels. The prisoners (sometimes also innocent children and women) were detained in terrible conditions and regularly faced torture (including fake executions). The Russian newspaper Nezavisimaya gazeta, which was anything but Dudayev-friendly, ar-

39 Kurier (Vienna) (29 December 1995), 4; Wiener Zeitung (Vienna) (29 December 1995), 1. Quoted by Pavel Felgenhauer in an opinion column in The Moscow Times (9 March 2000), 9.

41 Quoted in Novaya Gazeta (1 November 1999), 1.

42 Quoted in Michael Thumann, Das Lied von der russischen Erde. Moskaus Ringen um Einheit und Größe (Stuttgart/Munich: DVA, 2002), 177.

43 Quoted in Hannes Adomeit, "Das Militär in Tschetschenien: Hindernis auf dem Weg zu einer politischen Lösung," Diskussionspapier der Forschungsgruppe Russland/GUS 2 (February 2003); available at http://www.swp-berlin.org/produkte/diskussionspapier.php? PHPSESSID=45cc6cf828278fdf328f2a1 aa3a8f434\&id=1623\&active=none\&page=2. 
gued that the indiscriminate bombardments and the "filtration camps" were the root causes for the hostage crises in Budyonnovsk (June 1995) and Kislyar (January 1996). ${ }^{44}$ In October 1996, General Alexander Lebed, who had negotiated the first peace settlement, accused the Minister of the Interior, General Anatoli $\mathrm{Ku}$ likov, of having set up camps in which thousands perished. ${ }^{45}$ In 2000 there were reportedly thirty "filtration camps" in operation, holding somewhere between ten and twenty thousand detainees. ${ }^{46}$ The Chechen civilian population had to endure frequent so-called "cleansings" and "special operations." The Russian forces were particularly on the look-out for young men during their rebel search operations. Russian soldiers at checkpoints arbitrarily arrested and abducted Chechens; their relatives then received ransom demands - sometimes even for corpses. And according to the well-known Russian human rights organization Memorial, the Russian forces bombarded every cluster of Chechens they spotted. Even funerals were attacked. $^{47}$

The German Caucasus expert Uwe Halbach described the Russian campaign as a "war of extermination." "48 The well-known Russian human rights activist Lyudmila Alexeyeva compared the Russian actions in Chechnya with the German Wehrmacht's behavior in the USSR during World War II. ${ }^{49}$ The deputy chief of the General Staff, General Valeri Manilov, trumped all Russian cynicism concerning Chechnya. When asked why the war in Chechnya was lasting so long, he replied that the reason was Russia's "kindness and humanity."

Undoubtedly, the Chechen rebels have also committed human rights violations. Nevertheless, a report of the Legal Affairs and Human Rights Committee of the Parliamentary Assembly of the Council of Europe stated in 2002, "The scale and number of human rights violations and violations of international humanitarian law on the Chechen side cannot even remotely compare to those of the Russian side, and, due to Russia being a state party to the European Convention on Human

${ }^{44}$ Nezavisimaya gazeta (3 February 1996), 3.

45 Segodnya (18 October 1996), 1. At this time, Lebed had already lost his post as Secretary of the Russian Security Council.

46 Musa Jusupov, "Chechnya," in Mezhetnicheskie otnosheniya $i$ konflikty $v$ postsovetskikh gosudarstvakh - Ezhegodny doklad, eds. Valerij A. Tishkov and Elena I. Filippova (Moscow: Tsentr po izucheniyu i razresheniyu konfliktov Instituta etnologii i antropologii RAN / Set etnologicheskogo monitoringa i rannego preduprezhdeniya konfliktov, 2001), 239. "Itogi," NTV television network (23 November 1999); The Moscow Times (15 December 1999), 3.

48 Quoted in Das Parlament (18 November 2002), 12.

49 Izvestia (26 February 2003).

${ }^{50}$ Quoted in the Frankfurter Allgemeine Zeitung (5 February 2000). 
Rights and thus bound by duty to protect the rights she is violating, much more serious." $" 51$

\section{The Fighting in Chechnya}

After the invasion in 1999, the Russian forces, convinced of a swift victory, ruled out the possibility that the rebels would resort to guerilla tactics. However, guerilla warfare emerged in early 2000, and continues until today. The protracted guerilla war can only be explained by the existence of a certain level of civilian support.

In some of its aspects, the second campaign resembled a civil war. The rebels primarily targeted Chechens, who are considered as collaborators and traitors if they are employees of the Russian Militia and other security forces. The Kremlin deliberately sought to transform the conflict into an intra-Chechen conflict by mobilizing pro-Russian Chechens to fight the rebels. It took the Russian authorities in Chechnya more than two years after the start of the second war to stage a zachistka (mop-up operation) by a newly recruited Chechen unit in the town Starye Atagi. The Kremlin also attempted to "Chechenize" the conflict by backing Ramzan Kadyrov and his private militia. Unimpeded by the Russian authorities, this militia (among which there are many former rebels) continues to murder, rape, and loot.

The longer the second war lasted, the less likely it became that the Chechen resistance could strike the Russian Army a blow (like the reconquest of Grozny in 1996) that would force the Kremlin back to the negotiating table. However, the rebels have proven time and again that they are capable of striking targets all over Chechnya, even in Grozny and Khankala, where the Russian military headquarters are located. The rebels ambushed their enemies with sniper fire, portable antitank and air defense weapons, mines, and remotely-ignited bombs. Suicide attacks, a tactic well known from other asymmetric conflicts in Afghanistan, Iraq, Palestine, and Sri Lanka, did not occur during the first Chechen war, and were only introduced to the conflict in June 2000. A particularly devastating attack occurred on 27 December 2002, when two trucks loaded with explosives were blown up in front of buildings of the Russian-backed Chechen administration (and the FSB) in Grozny, killing more than seventy people. The highest concentration of suicide attacks occurred in the summer of 2003, when a wave of suicide bombings swept out of Chechnya and into Moscow.

\section{A Russian Military Victory Instead of a Peaceful Settlement}

Since the beginning of 2000, Moscow has proclaimed the end of the war many times over. ${ }^{52}$ But clashes continue even today. Moscow's notion of a "political

51 Quoted in Ib Faurby, "International Law, Human Rights, and the Wars in Chechnya," Baltic Defence Review 7:1 (2002): 106. 
process" for Chechnya was always confined to a number of demands (such as a forced return of Chechen refugees from Ingushetia, a referendum in 2003 on a new constitution that emphasizes the territory's association with Russia, ${ }^{53}$ a "dialogue" with Russian-installed and backed officials, and rigged elections ${ }^{54}$ ), and this process never involved negotiations with the rebels, which Moscow consequently labeled "terrorists." Moscow, as several Russian government representatives have pointed out in informal talks, is prepared (if necessary) to fight the war "until the last Chechen." The Kremlin instructed its army and secret services to ensure military victory at whatever cost, and since 1999 Russian forces stuck to this plan. Human rights have fallen into oblivion in Chechnya, although Russia has committed itself to human rights both in its constitution (see Articles 17-29 of its constitution) and in several international agreements (e.g., the Council of Europe, to which Russia acceded in 1996-during the first Chechen war, it should be noted).

\section{Conclusion}

In terms of organizational structure and relative strength of the combatants, both

${ }^{52}$ However, sometimes there are statements differing from this position. On 6 November 2006, Colonel Nikolai Varavin, the head of the press center of the so-called "Regional Operation Headquarters of the Antiterrorist Operation in Chechnya," admitted openly that the Chechen fighters "pose a serious threat" which the Russian-run Chechen Police were not capable of dealing with; see Liz Fuller, "Russia: Ministry Admits Chechen Resistance Still Poses 'Serious Threat'," RFE/RL (8 November 2006). Allegedly, 95.37 percent of the votes were in favor (with a voter turnout of 89 percent). In the Russian presidential elections on 14 March 2004, Vladimir Putin, who holds main responsibility for the invasion in 1999, allegedly received 92.3 percent of the votes in Chechnya (in Russia altogether he received 71.31 percent). In the Chechen presidential elections on 5 October 2003, the Kremlin-backed candidate Akhmed Kadyrov garnered 82.55 percent of the vote. After his assassination on 9 May 2004, Putin's new protégé, Alu Alkhanov, won 73.8 percent of the votes in the subsequent Chechen presidential election on 29 August 2004. In the Chechen parliamentary elections on 27 November 2005, 60.65 percent of the votes were assigned to the Kremlin-backed party "Unified Russia." In the Russian State Duma elections in Chechnya on 2 December 2007, allegedly 99.36 (!) percent of the populace voted for this party. And in the Russian presidential elections on 2 March 2008, officially 88.7 percent of the Chechen votes were counted for Putin's desired successor Dmitri Medvedev. 
the first and second Chechen wars were highly asymmetric. ${ }^{55}$ To counter Russia's overwhelming military power, which included air supremacy and an overwhelming monopoly on heavy and long-range weapons, the Chechen rebels resorted entirely to classical guerilla tactics. While Russia could fund its military campaign from its vast budget, which enjoyed tremendous expansion since 1999 due to high energy prices, the Chechen rebels never had any legal opportunities to finance their resistance. In addition, the asymmetry is also reflected in the number of casualties.

Compared to the first war, the political circumstances during the second war deteriorated markedly for the Chechen rebels. Under President Putin (2000-08), a new kind of "managed democracy" evolved in Russia. This increasingly centralized system is characterized by the curtailment of regional autonomy and a tendency towards creating an ethnocracy within the multi-ethnic Russian state. ${ }^{56}$ In addition, the function of the Russian media (especially of the television networks) was reduced from that of an institutional corrective to the role of an uncritical rapporteur that merely explained and defended Putin's policies. Whereas the rebels were able to get some positive media coverage during the first Chechen war, they had no chance during the second. Consequently, the Chechen rebels very soon lost the "war of information," adding another dimension of asymmetry to the conflict. Putin's control over the Russian media ruled out the possibility that internal pressure might mount and force the Russian government to find a political solution in Chechnya.

During the second Chechen war, the Russian government was very effective in

55 In Russia, only a comparatively small circle of scholars has devoted attention to the European and North American discourse about asymmetric warfare. See Vadim Volkov, "The Resources and Tactics of Terrorism: A View from Russia," in Business and Security: PublicPrivate Sector Relationships in a New Security Environment, eds. Alyson J.K. Bailes and Isabel Frommelt (Stockholm/Oxford: SIPRI/Oxford University Press, 2004), 111-18, especially 113-15; Igor Domin and Aleksandr Savinkin, "Asimmetrichnoe voevanie," Otechestvennye zapiski 5 (2005), available at www.strana-oz.ru/?numid=26\&article=1135, with references to Münkler; Aleksandr Manachinskii, "Kogda slabyy pobezhdaet silnogo," Nezavizimoe voennoe obozrenie (12 December 2006), available at http://nvo.ng.ru/wars/ 2006-12-22/2_slabyi.html (Manachinskii is a Kiev-based, pro-Russian retired colonel). And Ekaterina Stepanova, head of the Armed Conflicts and Conflict Management Program of the Stockholm International Peace Research Institute (SIPRI) and on leave from the Moscowbased Institute of World Economy and International Relations, has worked upon asymmetric warfare; see Ekaterina Stepanova, Terrorism in Asymmetrical Conflict: Ideological and Structural Aspects, SIPRI Research Report no. 23 (Stockholm/Oxford: SIPRI/Oxford University Press, 2008); Terrorism: Patterns of Internationalization, eds. Ekaterina Stepanova and Jaideep Saikia (London: SAGE Publications, 2009).

56 Since the beginning of 2005, there have been no governor elections in the regions (autonomous republics, oblasts, etc.). Instead of electing these officers, the heads of the executive branch in the regions are appointed by the President of the Russian Federation. 
conveying its message internationally. "By stressing a link between Chechnya and international terrorism, the Russian government managed to disguise the domestic and ethnoterritorial nature of the conflict and to portray the war internationally (in particular in the U.S. and in Europe) as a campaign against an externally controlled Islamist aggression." ${ }^{, 57}$ By curbing the Russian media and by linking the Chechen rebels to international terrorism, the Kremlin managed to almost silence both the domestic and the international public. The result was an "attention asymmetry" - a phenomenon where the world public barely takes notice of the conflict, although the death toll in Chechnya has far outstripped that in other well-covered hot spots, such as the Israel-Palestine conflict.

57 Manfred Sapper, "Ein schwieriger Balanceakt: Rußlands Irakpolitik in Zeiten des AntiTerror-Kampfes," Osteuropa 52:12 (2002): 1539. 


\section{Bibliography}

Adomeit, Hannes. Das Militär in Tschetschenien: Hindernis auf dem Weg zu einer politischen Lösung In Diskussionspapier der Forschungsgruppe Russland., 2003.

Arreguín-Toft, Ivan. "How the Weak Win Wars: A Theory of Asymmetric Conflict." International Security 26, no. 1 (2001): 93-128.

Arreguín-Toft, Ivan. "How the Weak Win Wars: A Theory of Asymmetric Conflict." International Security 26, no. 1 (2001): 97-99.

Beck, Ulrich. Der kosmopolitische Blick, oder Krieg ist Frieden. Frankfurt am Main: Suhrkamp, 2004.

Brzoska, Michael. "New Wars' Discourse in Germany." Journal of Peace Research 41, no. 1 (2004): 275-82.

Daase, Christopher. Kleine Kriege - große Wirkung: Wie unkonventionelle Kriegsführung die internationale Politik verändert. Baden-Baden: Nomos, 1999.

Declaration of the Government of the Russian Federation pertaining to the situation in the Chechen Republic and to regulative measures., 1999.

Domin, Igor, and Aleksandr Savinkin. "Asimmetrichnoe voevanie." Otechestvennye zapiski 5 (2005).

Fairbanks, Charles H.. "Weak States and Private Armies." In Beyond State Crisis? Postcolonial Africa and Post-Soviet Eurasia in Comparative Perspective, 132. Washington, D.C.: Woodrow Wilson Center Press, 2002.

Faurby, Ib. "International Law, Human Rights, and the Wars in Chechnya." Baltic Defence Review 7, no. 1 (2002): 106.

Felgenhauer, Pavel. Russian Strategy in the Chechnya Wars In Parameter bewaffneter Konflikte. Studien und Berichte zur Sicherheitspolitik. Vienna: Schriftenreihe der Landesverteidi-gungsakademie, 2000.

Fuller, Liz. "Russia: Ministry Admits Chechen Resistance Still Poses 'Serious Threat'." RFE/RL (2006).

Goble, Paul. "2002 Russian Census Results for Chechnya 'Contradicts Common Sense“." RFE/RL Caucasus Report 8, no. 32 (2002).

Halbach, Uwe. "Krieg am Rande Europas. Der Tschetschenienkonflikt in neuem Licht?" SWP-Aktuell 45 (2002): 4.

Itogi. NTV television network, 1995.

Jusupov, Musa. "Chechnya." In Mezhetnicheskie otnosheniya i konflikty v postsovetskikh gosu-darstvakh - Ezhegodny doklad, 239. Moscow: Tsentr po izucheniyu i razresheniyu konfliktov Instituta etnologii i antropologii RAN/Set etnologicheskogo monitoringa i rannego preduprezhdeniya konfliktov, 2001.

Kaldor, Mary. New and Old Wars: Organized Violence in a Global Era. Stanford, CA: Stanford University Press, 1999. 
Kasatkina, Tatyana I.. Rossiya - Chechnya: Tsep oshibok i prestuplenii. Moscow: Zvenya, 1998.

Krivosheyev, Grigoriy F.. Rossiya i SSSR v voynakh XX veka. Poteri vooruzhennykh sil. Statisticheskoe issledovanie. Moscow: OLMA-Press, 2001.

Mack, Andrew. "Why Big Nations Lose Small Wars: The Politics of Asymmetric Conflict." World Politics 27, no. 2 (1975): 181.

Maisaia, Vakhtang. "The Chechen Armed Forces: Contemporary Case." The Army and Society in Georgia (1999): 1-4.

Maksudov, Sergej. "Naselenie Chechni: prava li perepis?" Novye Izvestia (2002): 1, 5.

Malashenko, Aleksei, and Dmitri Trenin. Vremya yuga. Rossiya v Chechne - Chechnya v Rossii. Moscow: Gendalf, 2002.

Malek, Martin. "Russlands Kriege in Tschetschenien: 'Wiederherstellung der verfassungsmäßigen Ordnung,' 'Antiterror-Operationen' oder Völkermord?" Zeitschrift für Genozidforschung 5, no. 1 (2004): 102-29.

Manachinsk, ii, Aleksandr. "Kogda slabyy pobezhdaet silnogo." Nezavizimoe voennoe obozrenie (2006).

Mlechin, Leonid. Kreml. Prezidenty Rossii. Strategiya vlasti ot B.N. Yeltsina do V.V. Putina. Moscow: Tsentrpoligraf, 2002.

Münkler, Herfried. "Die privatisierten Kriege des 21. Jahrhunderts." Merkur 55, no. 623 (2001): 222-34.

Münkler, Herfried. "Wandel der Weltordnung durch asymmetrische Kriege." In Asymmetrische Kriegsführung - ein neues Phänomen der Internationalen Politik?, 91. Baden-Baden: Nomos, 2004.

Münkler, Herfried. Der Wandel des Krieges: Von der Symmetrie zur Asymmetrie. Weilerswist: Velbrück, 2006.

Münkler, Herfried. Die neuen Kriege . Reinbek bei Hamburg: Rowohlt, 2002.

Sapper, Manfred. "Ein schwieriger Balanceakt: Rußlands Irakpolitik in Zeiten des AntiTerror-Kampfes." Osteuropa 52, no. 12 (2002): 1539.

Serebryannikov, Vladimir. "Sotsiologiya voyny." Nauchny mir (1997): 159.

Stahel, Albert A.. "Dissymmetrischer Krieg versus asymmetrischer Krieg." Allgemeine Schweizerische Militärzeitschrift 168, no. 12 (2002): 3.

Stahel, Albert A.. "Simulationen asymmetrischer Kriege." Allgemeine Schweizerische Militärzeitschrift 167, no. 11 (2001): 22.

Stepanova, Ekaterina. Terrorism in Asymmetrical Conflict: Ideological and Structural Aspects In SIPRI Research Report. Stockholm/Oxford: SIPRI/Oxford University Press, 2008. 
Thumann, Michael. Das Lied von der russischen Erde. Moskaus Ringen um Einheit und Größe. Stuttgart/Munich: DVA, 2002.

Van Creveld, Martin. "Grausamkeit oder Zurückhaltung. Wie reguläre Armeen asymmetrische Kriege gewinnen können." Internationale Politik 61, no. 4 (2006): 87.

Van Creveld, Martin. Die Zukunft des Krieges. München: Gerling Akademie Verlag, 1998.

Volkov, Vadim. "The Resources and Tactics of Terrorism: A View from Russia." In Business and Security: Public-Private Sector Relationships in a New Security Environment, 111-18. Stockholm/Oxford: SIPRI/Oxford University Press, 2004.

Zolotarev, Vladimir A.. Rossiya (SSSR) v lokalnykh voynakh i voennych konfliktakh vtoroy poloviny XX veka. Moscow: Kuchkovo Pole, 2000. 